\title{
Comparative study on board structure and performance between domestic and foreign banks in Malaysia
}

\section{Haslindar Ibrahim (D), Ng Yi Xiang, Nik Hadiyan Nik Azman (D), Abdul Hadi Zulkafli}

School of Management, Universiti Sains Malaysia,

11800 USM, Penang, Malaysia

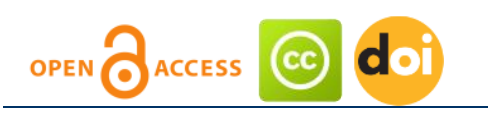

Article history:

Received: December 12, 2017

1st Revision: April 7, 2018

Accepted: September 19, 2018

\section{JEL classification:}

E58

G21

G28

DOI:

10.14254/jems.2018.3-2.4

\begin{abstract}
This study examines the performance of domestic and foreign banks with regards to the relationship between the board structure and their financial performance in Malaysia. The sample consists of 8 domestic banks and 16 foreign banks in Malaysia from 2012 to 2016.The board structures are board size (BS) and proportion of independent director (ID) as an independent variables and firm size as the control variable. Meanwhile, the performance is measured by four ratios, liquidity (current ratio), profitability (return on assets), risk and solvency (loan to deposit ratio) and efficiency performance (asset utilization ratio). The findings reveal that the board size is proved to be significant relationship with return on assets (ROA) as well as loan to deposit ratio (LDR) for both domestic and foreign banks but insignificant with the other ratios of both the domestic and foreign banks. Apart from that, independent director proportion showed an insignificant influence on financial performance with four financial ratios for both domestic and foreign banks. This study suggests that both domestic and foreign banks do have difference in terms of financial performance, domestic banks perform better than foreign banks in terms of generating good return on assets and loan to deposits ratio however foreign banks perform far better in terms of level of liquidity of the banks as compared to domestic banks.
\end{abstract}

Keywords: risk and solvency, liquidity, efficiency performance, board structure, domestic and foreign bank, sustainability. 


\section{Introduction}

Financial institutions like banks serve a very crucial role in the economy by intermediating funds from depositors to events that assist corporation and support economic growth, which states by Bank for International Settlements (2014). Therefore, effective corporate governance is crucial to the appropriate functioning of the banking sector and the economy as whole. Corporate governance failures will be undeniably tied to underlying market failures. The role of information and disclosure in mitigating both fundamental market failures and their proximate manifestations will classify as governance failures. While current research suggests that information is an integral part of governing financial institutions and addressing systemic risk in the financial system, further research is required to understand the complexities of the production, use, and quality of information in financial markets.

The Basel Committee on Banking Supervision (BCBS) has emphasized the need to study, understand, and improve the corporate governance of financial entities. The significance of this is to diffuse the belief that good corporate governance increases monitoring efficiency. Apart from that, the committee believes that corporate governance is essential to ensure a sound of financial system and a country's economic development. Currently, there are plenty of researches on the issue of corporate governance, however surprisingly, study focusing on banks' corporate governance still insignificant in value. The inadequate of collective action confronted by stakeholders who wish to assure the efficient allocation of resources and the distribution of quasi rents as well as the problems derived from different types of ownership and control, are truly related to financial entities.

From the corporate governance side, the board of directors in bank plays a crucial role in bank governance, such as monitoring managers' behaviour and giving advices on identification and implementation of strategies (Andres \&Vallelado, 2008). In present studies, they indicated that bank with larger boards tends to have lower liquidity but higher risk and profitability, however, in some studies in other countries such as Thailand showed that smaller board size enhance the overall financial performance of bank. Based on this, it is a good potential to look at whether the differences in board size will affects significantly to the banks' financial performance.

In fact, banks can enhance their performance by including more independence directors as being suggested by Pathan, Skully and Wickremanayake (2008). This study suggests that bank shareholders, creditors, depositors and regulators might benefit from policies that encourage independent boards. The result depicted that return on asset (ROA) and return on equity (ROE) are positively correlated with board independence but the relationships are not significant. However, empirical findings on board independence and firm performance have been mixed. Therefore, the policies implemented by Malaysian Code of Corporate Governance, which stated that all listed companies should contain minimum number of independence directors, does it stand as benefits for the banks in term of performance? Additionally, the subsequent question would be how much of proportion of independence directors should include in order to achieve sufficient and satisfying performance? Thus, study should be carried out in-depth to show the impact of independence of directors on firm performance in Malaysia so that domestic stakeholders could have a clearer picture pertaining to these issues.

From the aspects of domestic and foreign banks, which several authors have addressed the potential benefits of foreign bank entry for the domestic economy in terms of better resource allocation and higher efficiency (Levine, 1996; Walter \& Gray, 1983; and Gelb \& Sagari, 1990). Levine (1996) specifically mentions that foreign banks may firstly improve the quality and availability of financial services in the domestic financial market by increasing bank competition, and enabling the greater application of more modern banking skills and technology. Secondly serve to stimulate the development of the underlying bank supervisory and legal framework, and thirdly enhance a country's access to international capital. There may also be costs to opening financial markets to foreign competition. Stiglitz (1993), for instance, discusses the potential costs to domestic banks, local entrepreneurs, and the government resulting from foreign bank entry. Domestic banks may incur costs since they have to compete with large international banks with better reputation, therefore local entrepreneurs may receive less access to financial services since foreign banks generally concentrate on multinational firms, and governments may find their control of the economy diminished since foreign banks tend to be less sensitive to their wishes. Thus, this study intends to test whether there is a significant difference between these two types of banks in Malaysia. According to Sufian (2009), this study analyzes the factors influencing bank profitability in Malaysia covering the period 2000-2004 and this study focuses only on foreign and domestic commercial banks. This study found that, there is a negative relationship between credit risk and loan concentrated for Malaysian banks. This is due to the higher the credit risks of a bank, the more its exposure to loan payment, which will result consequently in a low level of profitability. 
Therefore, the purpose of the study is to investigate the relationship between board structure as measured by board size (BS) and the proportion of independent director (ID) with the financial performance as proxies by current ratio (liquidity), return on assets (profitability), loan to deposit ratios (risk and solvency) and asset utilization ratio (efficiency performance). The interest to conduct this research is important to address these issues and shortcomings so that this study can provide a better suggestion in helping to sort out the tools of problem-solving. This study also is important for the companies and executives to sort out a better board composition that could enhance the banks' board effectiveness and performance.

The remainder of this paper is organized as follows. Section 2 discusses the relevant literature on development of domestic and foreign banks, board structure, financial performance, and hypothesis development. Section 3 describes the methodology and data. Section 4 presents the main results and discussions of the findings. Section 5 concludes and provides some implications.

\section{Literature Review}

\subsection{Development of Domestic Banks and Foreign Banks in Malaysia}

The Malaysian banking system is broadly being divided into the banking sector and nonbank financial intermediaries. These two groups differ from each other with respect to their activities. Out sizing non-bank intermediaries significantly, the banking sector accounts for approximately $70 \%$ of the banking system's total assets. Commercial banks are the main players in the banking sector and are the largest and most significant providers of funds. As at end-2008, the commercial banking sector dominates the Malaysian financial system's assets and liabilities, with total assets and liabilities amounting to RM1600.5 billion ( $\$ 462.6$ billion). There were 9 domestically incorporated and 13 locally incorporated foreign commercial banks in Malaysia as at end-2008. As of 2017, the number of domestic banks is reduced to 8 and locally incorporated foreign commercial banks increased up to 19 in Malaysia, which means there are 27 domestic banks and foreign banks in total around Malaysia.

Figure 1: Total Foreign Bank Claims on Malaysia (in percent of Malaysian GDP)

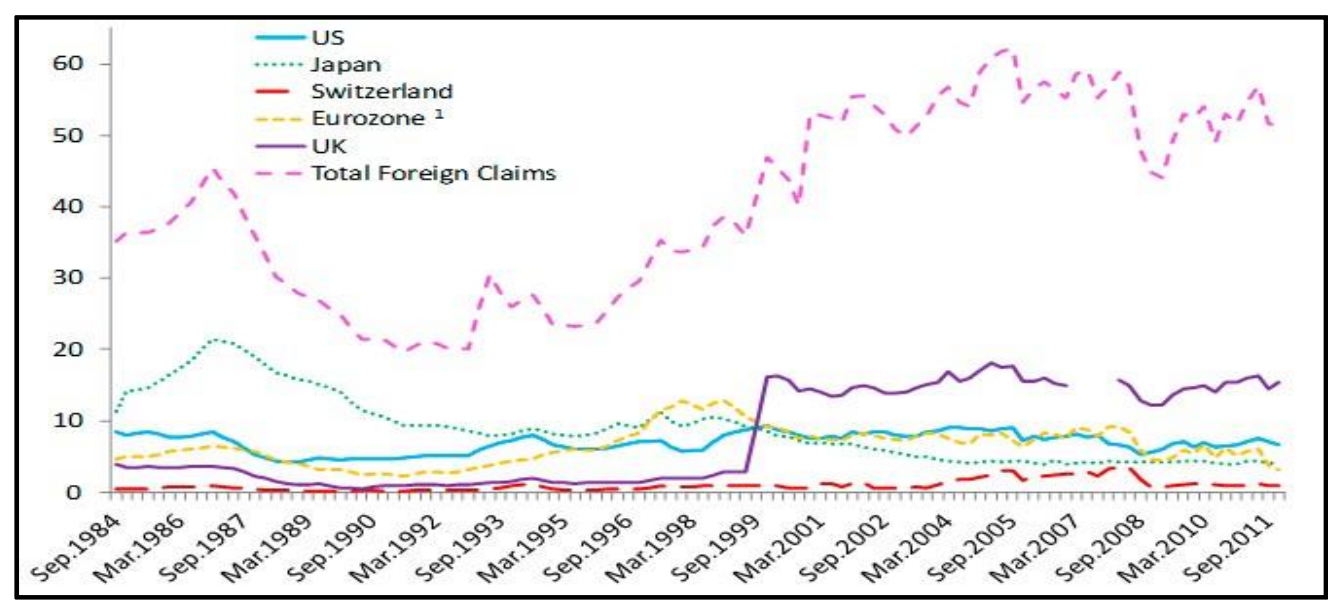

In spite of the Asian Financial Crisis (AFC), foreign claims of Bank of International Settlements (BIS) reporting banks on Malaysia have generally been on an increasing trend since the early 1990s, which the trend can be seen in the Figure 1. Up until the mid-1980s, Japanese banks expanded significantly their claims on Malaysia, reaching a peak of around 20 percent of GDP. This was associated with some major Japanese Foreign Direct Investment (FDI) in Malaysia in the earlymid 1980s. However, Japanese bank exposures to Malaysia started falling soon after as Thailand and Indonesia became more popular FDI destinations in ASEAN, in other words their influence was already diminishing well before the Japanese financial crisis became systemic. From the early 1990s, Eurozone banks and the U.S. banks helped fuel the boom until the AFC, as they expanded credit provision relative to GDP (Figure 2). After the AFC, the exposure of Eurozone and the U.S. banks has generally diminished, with the Singaporean and the U.K. retaining preeminence in the 2000s. Since 2000, total foreign claims have hovered above 50 percent of GDP, with those of the U.K. at around15 percent of GDP. While the BIS do not publish Singaporean bank claims, their claims on Malaysia are included in the total, and it is about 20 percent of Malaysian GDP. 
Figure 2: Foreign banks losing market share in Malaysia

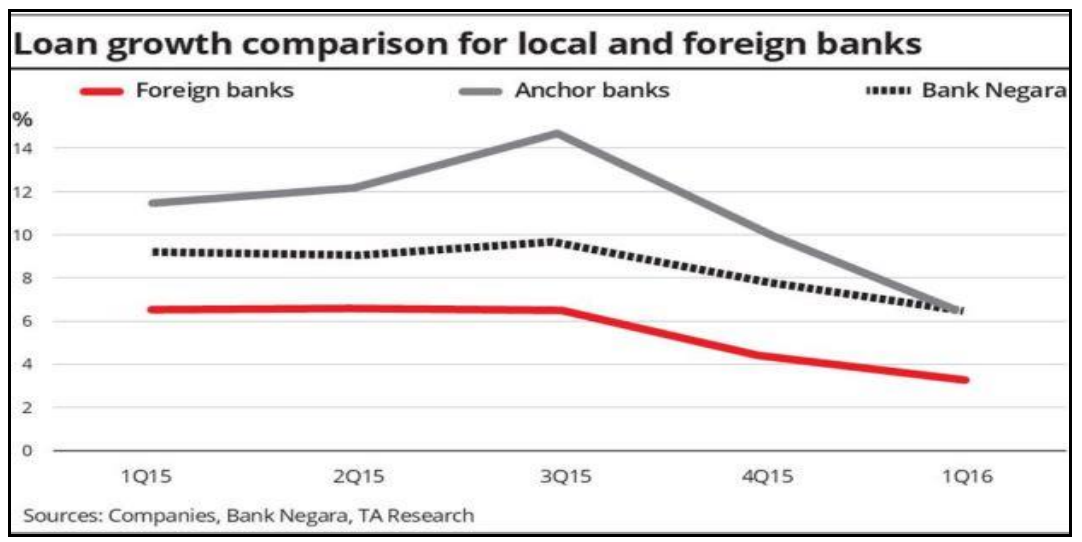

Furthermore, the statistics from Bank Negara in the year 2016 indicated that foreign banks have been losing market share on Malaysian turf. Unlike the domestic bank players, the foreign banks appeared to be increasingly cautious on the small and medium enterprises as well as the consumer segment, with loans in both declining at a faster pace than the domestic players and Bank Negara. According to the information extracted from the Central Bank of Malaysia (Bank Negara Malaysia), there are 27 domestic banks and foreign banks in total around Malaysia, in which there are 8 domestic banks and 19 foreign banks, in which Malayan Banking Berhad (MB) is the top among all the domestic and foreign banks in Malaysia with the highest total assets of RM 627,966,091.80 ('000), followed by CIMB Bank Berhad with the total assets of RM 413,774,868.60 ('000). One of the significant statistics is that the overall total assets of domestic banks is RM $1,976,877,698.40$ ('000) are higher than overall total assets of foreign banks which is RM406,509,091.20 ('000) as shown in Table 1 and Table 2.

\begin{tabular}{lcc}
\hline Table 1: Total Assets of respective domestic bank in Malaysia & \\
\hline Symbol & Domestic Banks & Total Assets (RM'000) \\
\hline AF & Affin Bank Berhad & $57,623,717.00$ \\
ALLB & Alliance Bank Malaysia Berhad & $39,929,891.60$ \\
AM & AmBank (M) Berhad & $130,160,471.00$ \\
CIMB & CIMB Bank Berhad & $413,774,868.60$ \\
HLC & Hong Leong Bank Berhad & $170,656,666.20$ \\
MB & Malayan Banking Berhad & $627,966,091.80$ \\
PB & Public Bank Berhad & $334,016,464.00$ \\
RHBC & RHB Bank Berhad & $202,749,528.20$ \\
\hline
\end{tabular}

\begin{tabular}{llc}
\hline Symbol & Foreign Banks & Total Assets (RM'000) \\
\hline BNP & BNP Paribas Malaysia Berhad & $3,073,218.20$ \\
BKK & Bangkok Bank Berhad & $3,996,244.80$ \\
BOA & Bank of America Malaysia Berhad & $2,679,942.60$ \\
BAC & Bank of China (Malaysia) Berhad & $8,099,496.40$ \\
TOK & Bank of Tokyo-Mitsubishi UFJ (Malaysia) Berhad & $19,268,106.80$ \\
CITI & Citibank Berhad & $38,286,151.40$ \\
HSBC & HSBC Bank Malaysia Berhad & $82,941,612.00$ \\
ININ & India International Bank (Malaysia) Berhad & $444,068.60$ \\
INC & Industrial and Commercial Bank of China (Malaysia) Berhad & $3,996,695.60$ \\
MIZU & Mizuho Bank (Malaysia) Berhad & $2,525,549.80$ \\
ABU & National Bank of Abu Dhabi Malaysia Berhad & $846,671.40$ \\
OCBC & OCBC Bank (Malaysia) Berhad & $87,032,608.60$ \\
SC & Standard Chartered Bank Malaysia Berhad & $51,222,592.20$ \\
SMBC & Sumitomo Mitsui Banking Corporation Malaysia Berhad & $5,581,455.60$ \\
SCOT & The Bank of Nova Scotia Berhad & $4,428,119.40$ \\
UOB & United Overseas Bank (Malaysia) Bhd. & $92,086,557.80$ \\
\hline
\end{tabular}




\subsection{Theories of Corporate Governance, Stewardship and Agency}

According to Malaysian High Level Finance Committee (1999), corporate governance can be defined as the process and structure used to direct and manage the business affairs of the company towards enhancing business prosperity and corporate accountability with the ultimate objective of realizing long-term shareholder value whilst taking into account the interest of other stakeholders. Besides, Mathiesen (2002) mentioned that corporate governance is a field in economics that investigates how to secure or motivate efficient management of corporations by the use of incentive mechanisms, such as contracts, organizational designs and legislation. These underlying ideas and concepts of corporate governance have been slowly evolved since our ancient time. It was first used in 1960 and has been quickly adopted globally since 1980sand today, researchers can access to over 110 million references to corporate governance.

Corporate governance seemed to be growing well around the whole world as the $21^{\text {st }}$ century. In fact, some large companies such as Enron, Waste Management, World.com and Tyco collapsed due to the governance failure and involvement in accounting fraud. Since then, the US Sarbanes-Oxyley Act 2002 was placed to impose stricter demands for the governance of all listed companies in the United States. In 2007, Subprime Mortgage Crisis occurred due to the failure for directors to act in the best interest on behalf their shareholders. In 2010, Organisation for Economic Co-operation and Development (OECD) is required to support other countries in developing their own corporate governance codes and the corporate governance practices continue to evolve and being adopted until today published the Principles of Corporate Governance.

Basically, related to this study, there are two theories adopted such as the agency theory and stewardship theory. The agency theory is adopted due to the existence of independent directors. Agent-principal issue will exist when the agency relationship in finance occurs between shareholders (principal) and company executives (agents) such as Chief Executive Director (CEO). The agency issue has long been recognized and has become a challenge for the enterprises in this modern era. The agency theory provides a unique insight, realistic, and empirically valid perspective on problems of cooperative effort. However, the agency theory has its limitation. For example, the agency problem includes asymmetrical information access and difference of propensity towards risk between principal and agents has caused the conflicts as well as indicating the limitation of this theory. Jensen and Meckling (1976) proposed that despite agency theory receives criticism, it remains a critical theory for every principal and agent to consider with whenever facing any corporate governance issue in the corporate world.

The agency theory assumes that the interests of principal and agents are diverged. According to agency theory, the principal can limit the opportunistic action by the agent by incurring monitoring costs, hence, by establishing incentives to limit divergence between interests of principal and agent. Hilland Jones (1992) explained the agency theory as one in which one or more persons (the principals) engage with another person (the agent) to perform some service on their behalf which involves delegating some decision making authority to the agent. In the past, agency theory has been the dominant model in the financial economics literature. According to the literature, agency theory illustrates and concerns more about the relationship between managers and shareholders (Jensen \& Meckling, 1976). Nowadays the theory has been expand to explain the nature of the implicit and explicit contractual relationships that exist between a firm's employees, customers, suppliers, creditors, communities, and the general public. The agency theory views the stakeholders of a firm as a bond ofcontracts. As mentioned by Eisenhardt (1989), the agency theory emphasizes on the importance of incentives and self-interest in organizational thinking and organizational life. Thus, principal can invest in information systems to confine agent from carrying out opportunistic actions. Apart from that, the agency theory expand the organizational thinking as well by taking account the consequences of outcome and willing to accept risk into the contracts between agent and principal.

Besides the agency theory, the stewardship theory is also being applied in this study. These theoretical considerations argue a view of managerial motivation alternative to agency theory and which may be termed stewardship theory (Donaldson 1990a, 1990b; Barney 1990). Regarding to stewardship theory, it holds that there is no inherent and general problem of executive motivation. Provided the absence of an inner motivational problem among executives, there is the question mark on head whether how far executives can achieve the good corporate performance to which they aspire. Hence, stewardship theory holds that performance variations arise from whether the structural situation in which the executive is located facilitates effective action by the executive. The issue becomes whether or not the organization structure helps the executive to formulate and implement plans for high corporate performance (Donaldson, 1985). This theory believes that cooperative is more effective than individualistic behavior in order to maximize the shareholder wealth. Meanwhile, the shareholders must carefully authorize the governance structure and 
mechanisms to facilitate the authority for the Chief Executive Officer (CEO) to execute the proorganizational actions that provide the greatest utility for shareholders.

\subsection{Hypothesis Development}

It is important to recognize that several studies have been done in order to examine the factors influencing bank performance or profitability such as Short (1979) and Bourke (1989). Furthermore, there are also few studies focusing on country or region such as Molyneux and Seth (1996), Matthews and Ismail (2005), Gerlach, Peng and Shu (2005), Varadi, Mavaluri, Boppana and Nagarjuna (2006), Nimalathasan (2008), Sufian (2009), Flamini, McDonald and Schumacher (2009), Davydenko (2010), Said and Tumin (2011), Gul et al. (2011). Molyneux and Seth (1996) found that the capital strength and demand on loan have positive effect on the foreign bank profitability however unrelated to an improvement in commercial lending and in order to generate higher profitability, a foreign bank should deal with a considerable capital.

This study examine the determinants of the bank's board size and independence director on the bank's financial performance in term of liquidity ratios, profitability ratios, risk and solvency ratios and efficiency ratios. The discussion will be done on each and every of the independent and dependent as well as the control variables

\subsubsection{Board Size and Financial Performance}

Delis, Gganis and Pasiouras (2009) stated that existing studies on banking have mostly ignored the effect of board characteristics on bank liquidity risk. The findings released that the larger of the board size will convey a negative impact to the bank liquidity. The reasons were the board with larger size more likely to hold less liquid assets and invest large portion of their portfolios in risky events in order to gain higher return and profit in the good times. However, this approach was very risky as in the bad times, the bank might face significant default risk due to low level of liquidity (CR) and capitalization. According to Belkhir (2009) who did a study on a sample of bank holding companies and savings and loan holding companies from year 1995 until end of year 2002. The results showed that the number of directors is positively associated with the return on assets (ROA) of a bank. In this study, by using regression models to test the data collected, it revealed that there was significant evidence indicating a positive relationship between board size and bank performance. The evidence also disclosed the board expand was regarding to an increase in bank total assets or bank size. Besides, Switzerand Sahut (2015) found that larger and diversified board could benefit banks in distress states or when credit risk was overriding. It was because when banks were in financial distress, they would find their investment policies tightened up, and default was very likely, hence, smaller boards are getting higher chances to bankrupt. Thus, they believed that there was a negative relationship between board size and bank credit risk (LDR).Thus, below are the testable hypotheses for this study.

H1a: Board size is positively related to liquidity ratio.

H1b: Board size is positively related to profitability ratio.

H1c: Board size is negatively related to risk and solvency ratio.

H1d: Board size is positively related to efficiency ratio.

\subsubsection{Independent Director and Financial Performance}

There are various elements associated with banking crises such as the degree of dependence on interest-sensitive funds, the accessibility to the money market, the volatility ofdeposits and the availability of assets readily convertible into cash. All of these elements are crucial to the banking industry, as they will affect the level of bank liquidity risk, thus board characteristics are liable for influencing the bank liquidity (CR). Past studies disclosed that independent directors hold higher proportion of share would result in higher percentage of liquid assets in bank. However, too much liquidity was unnecessary for banks especially during economic up trend period, hence there was no need for too many independent directors in the board. Therefore, banks with more independent directors showed more conservative towards liquidity risk (Delis, Gganis \& Pasiouras, 2009).

Rowe, Shi, and Wang (2011) stated that the bank profitability caused by the influence of independence directors deserves specific investigations as they were critically important for bank governance and they were representing all small shareholders to express their major opinions and views. Belkhir (2009) described that the coefficient measured on board independence are negatively related to return of assets (ROA) of banks. The studies tested that by increasing the members of independence directors at banking industry did not enhance the bank's performance, 
in other respects, it may negatively affect the performance. Overall, according to the most recent studies, the proportion of board independency was positively related to the return on assets of banks. Besides, Dionne and Triki (2005) identified that board's independence is positively associated with corporate efficiency. The New York Stock Exchange's listed companied requires a majority of independent directors in the board. The results justified that independent directors were viewed as important role in monitoring as their jobs are not overlap to the firm's CEO's responsibility and they were free to make any decisions without being worried and afraid of their position and compensation being threaten. So, the proposed hypotheses are:

H2a: The proportion of independent directors is positively related to liquidity ratio.

$H 2 b$ : The proportion of independent directors is positively related to profitability ratio.

H2c: The proportion of independent directors is negatively related to risk and solvency ratio.

H2d: The proportion of independent directors is positively related to efficiency ratio.

\subsubsection{Domestic Banks and Foreign Banks Financial Performance}

According to Demirguc-Kunt and Huizinga (1999) and Claessens et al. (2001), these studies found that foreign banks lose competitive advantage as compared to domestic banks in developed countries despite of having this as a comparison in less developed countries. To add, Fries and Taci (2005) examine the cost efficiency in 15 post-communist countries. The results indicate that privatized banks with majority foreign ownership are the most cost efficient ones and those with domestic ownership are the least, though both being more efficient than state-owned banks, in which this result is found in a more recent period. Studied by Staikouras and Wood (2003) showed that, the performance of a sample list of banks operating in thirteen European Union banking markets. The outcomes show that loans to assets ratio (LDR) and the proportion of loan loss provisions are inversely related to banks' return on assets, as well as that banks with greater levels of equity are relatively more profitable. Besides, Kosmidou et al. (2004) stated that the outcome shows that domestic banks in fact display a higher overall performance compared to foreign banks operating in the country of United Kingdom. In a more recent study that carried out by Kosmidou et al. (2006a), the research examines how foreign banks differ from domestic banks in the United Kingdom and find that the later are characterized by higher return on equity, net interest revenue to total earning assets, and loans to customer and short term funding.

Finally, findings explained that there were no significant difference in efficiency measure between 24 commercial domestic banks and foreign banks in Malaysia. The empirical studies indicated that foreign banks have a higher efficiency level than domestic banks, efficient banks are characterized by size but not profitability or loan quality, currently domestic banks were performing poorer compared to foreign banks on the basis of their operational efficiency level and business model (Matthews and Ismail, 2006). However, in Malaysia, the foreign mainstream banks were performing better in terms of asset utilization ratio (AU) compared to domestic banks (Rosly \& Abu Bakar, 2003). Therefore, the proposed hypotheses are:

H4a: There is a significant difference between domestic banks and foreign banks from the aspect of liquidity ratio.

H4b: There is a significant difference between domestic banks and foreign banks from the aspect of profitability ratio.

H4c: There is a significant difference between domestic banks and foreign banks from the aspect of risk and solvency ratio.

H4d: There is a significant difference between domestic banks and foreign banks from the aspect of efficiency ratio.

\section{Methodology and Data}

The following section shall be discussed on the methodology, data collection and measurements of determinants.

\subsection{Samples Selection}

Data from year 2012 to 2016 was selected, which consist of 8 domestic and 16 foreign banks, which sums up to 24 domestic and foreign banks. Judgment sampling as one of the Non-Probability Sampling was applied as it involves only selecting elements to provide the information required. For example, the only selected elements in this research are all the domestic banks as well as 
completely locally incorporated foreign banks. Table 3below show the sampling technique used and the sample size in this study:

Table 3: Total sample size of domestic and foreign banks

\begin{tabular}{lcc} 
& Domestic & Foreign \\
\hline Total banks in Malaysia & 27 & 27 \\
Less: Foreign ownership banks & 19 & 8 \\
Less: Domestic ownership banks & 3 \\
Foreign Bank (unfound) & $\mathbf{8}$ & $\mathbf{1 6}$ \\
Total & & \\
\hline
\end{tabular}

\subsection{Independent Variable}

The following section shall be presenting the board size and independent director.

\subsubsection{Board Size}

Board size is defined as the number of directors constituting the board of a company that has the right to attend the shareholders' annual meeting and influence the company performance positively or negatively (Jensen, 1993; Belkhir, 2009). The way of measure the board size is:

Board size $=$ Total number of directors in the board

\subsubsection{Independent Director}

According to Hishamuddin (2004), an independent director is separated from the firm's routine's operations. Independent director is a party who is no business or family ties to company management, and a party who is liable to many constituencies such as deal with the firm's customers, workers and suppliers (Belkhir, 2009; Clarke, 2009). Therefore, firms can expect numerous inputs and updates from independent members, which have an independent view, expertise and skills that can bring ideas in a professional manner. Independent director is measured as the proportion of independent directors to total number of directors on the board of the company. The variable of independent director is described as:

Proportion of Independent Director $=\frac{\text { Number of Independent Directors }}{\text { Total Number of Directors on Board }}$

\subsection{Dependent Variables}

The following section shall be discussing on liquidity ratios, profitability ratios, risk and solvency ratios and efficiency ratios.

\subsubsection{Liquidity Ratios}

Liquidity ratio measures the capability of bank to meet its short-term obligations and relationship between firm's liquid asset (current assets) and current liabilities (Cornett, Adair and Nofsinger, 2015; Abdullah, 2011). The current ratio (CR) is chosen in this study and the ratio's formula is stated as:

$$
\text { CurrentRatio }=\frac{\text { Current Assets }}{\text { Current Liabilities }}
$$

Acceptable current ratios differs from sector to sector and normally ranged 1.5 to 3 for healthy business. Low value for current ratio $(\mathrm{CR}<1.00)$ showed firms may have difficulty it meeting short-term obligation. Higher value $(C R>1.00)$ indicates company is more likely to meet current obligations.

\subsubsection{Profitability Ratio}

Profitability ratio explained as a ratio with the combination of effect of liquidity, asset management and debt management on firm's operating results. This ratio also assesses the 
capability of company to generate earnings as compared to its expenses and other relevant costs incurred during certain period of time (Abdullah, 2011; Cornett, Adair \& Nofsinger, 2015). Return on assets (ROA) is chosen for this research and this ratio is illustrated as:

$$
\text { ReturnonAssets }=\frac{\text { Net Income on Common Stockholders }}{\text { Total Assets }}
$$

If the return on assets (ROA) is 0.175 , it means the bank generates 17.5 cents of profit for every dollar of assets hold by the bank. The higher ratio displayed the higher profitability of the bank, whereas the lower value the lesser profitability of the bank.

\subsubsection{Risk and Solvency Ratio}

Risk and solvency ratio showed a bank's ability to generate cash flow and pay for its debts and other long-term financial obligations (Ika and Abdullah, 2011; Ansari and Rehman, 2011). Loan to deposit ratio (LDR) is selected for this study and the formula is:

$$
\text { LoantoDepositRatio }=\frac{\text { Loan }}{\text { Deposit }}
$$

If the ratio shows too high value ( $>1.00$ ), it carries a meaning that banks may not have enough liquidity to cover future fund requirement and the banks may rely on its loan more than its deposits for generating income. However, if the ratio is too low $(<1.00)$, the banks may not earning much and may rely on its own deposits to make loan to its customers, without any borrowing.

\subsubsection{Efficiency Ratio}

Efficiency ratio measures the efficiency of a company and how well a company uses its assets and liabilities internally (Cornett, Adair \& Nofsinger, 2015; Abdullah, 2011). Asset utilization ratio (AU) will be used in this research and the formula is shown below:

$$
\text { Asset Utilisation Ratio }=\frac{\text { Total Operating Income }}{\text { Total Asset }}
$$

If asset utilization ratios have a value of 3, it explains that the bank generates RM 3 in sales for each dollar of assets, which means the higher value of this ratio the more effective of the respective bank.

\subsection{Control Variable (Firm Size)}

Firm size in this study is interpreted as the amount of property, amount of sales or total number of employee in the banks. However, it is hardly to define whether the banks are large or small as the actual figures of the elements stated above are difficult to identify (Yasuda, 2005).In this study, firm size is measured by the natural log of book value of total assets of the company (Florackis \& Ozkan, 2004; Anderson \& Reeb, 2003; McKnight \& Mira, 2003; and Ang et al., 2000).

\subsection{Regression Model}

Regression model between board structure and bank's financial performance as in follow:

$$
F R=\alpha+\beta_{1} B S_{i t}+\beta_{2} I D_{i t}+\beta_{3} F S i t+\varepsilon_{i t}
$$

Where:

$F R=$ Liquidity ratio, Profitability ratio, Risk and solvency ratio and Efficiency ratio

$B S=$ Board Size

$I D=$ Independent director

FS = Firm size

Due to the merits of concerning time-series analyses and cross-section factor, panel data analysis will be used to estimate the above model. There are three possible variations of panel data analysis which are ordinary least square (OLS), the fixed effects model and the random effects 
model in the panel data analysis. After the Hausmans test, the fixed effects model is the best model to be used in this study.

\section{Results and Discussions} study.

The following part shall be discussing about the results and discussions for this research

\subsection{Descriptive Statistics}

Table 4 displays the descriptive statistics of the dependent and independent variables from the year of 2012 to 2016.This results include mean and standard deviation of the variables such as board size (BS), independent director (ID), firm size (FS), current ratio (CR), return on assets (ROA), loan to deposit ratio (LDR) and asset utilization ratio (AU) for full sample, domestic and foreign banks. According to the tested outcome, there is a difference between the mean of domestic banks and foreign banks in each variable. Most of the variables for domestic banks have larger mean compared to foreign banks, except mean for current ratio (CR), and for asset utilization (AU). The current ratio mean of foreign banks is 1.634356 whereas domestic banks are1.029360. It may explain that foreign banks have better liquidity performance compared to domestic banks.

Meanwhile, the asset utilization ratio mean of foreign banks is 0.025433 whereas the mean

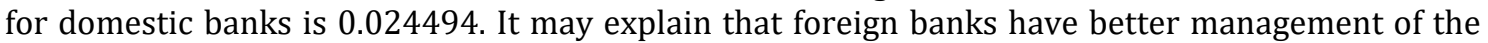
returns on the invested assets within its organization compared to domestic banks. Hence, the full sample statistics show the overall mean for current ratio is 1.432690 . The means for other variables of foreign banks such as board size (6.4250), independent director proportion (0.472324), firm size (15.945115), return on asset (0.006282), and loan to deposit ratio (0.660496) indicate relatively lesser values compared to domestic banks' variables such as board size (9.6750), independent director proportion (0.533546), firm size (18.983067), return on asset (0.010897), and loan to deposit ratio (0.815687). In addition, the mean for each variable of overall full sample is board size (7.5083), independent director (0.492731), firm size (16.957766), current ratio (1.432690), return on asset $(0.007820)$, loan to deposit ratio $(0.712226)$ and asset utilization ratio $(0.025120)$ respectively.

Based on the result shown in Table 4, the board size for foreign banks have lesser broad range (5.00-8.00) compared to domestic banks (7.80-12.00). In fact, the range of firm size also indicates a difference between domestic banks (17.5026-20.2580) and foreign banks (13.003718.3382), but the proportion of independent directors showed only a narrow range for both banks. The performance of both banks in term of return on asset (ROA), loan to deposit ratio (LDR) and asset utilization ratio (AU) showed a smaller range for both type of banks, however a range for current ratio (CR). Besides, the current ratio (CR) of domestic banks has a better performance compared to foreign banks. Overall, there is a huge range for every variable as it compromises of all data collected from both types of banks.

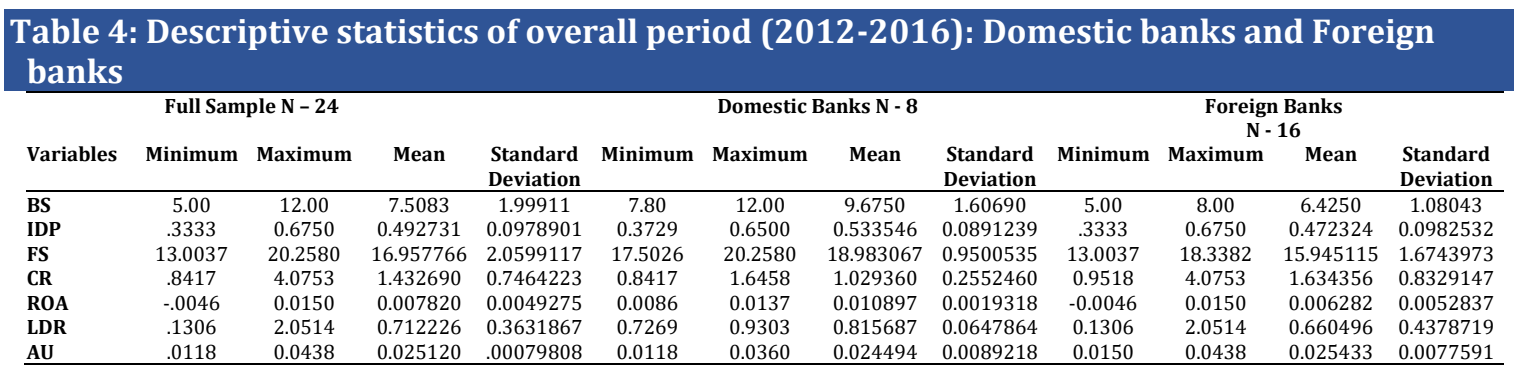

\subsection{Independent samplest-test}

An independent samples t-test is a test, which is used to determine if there are any significant differences between two groups in the variable of interest. Many researchers are keen to study about whether two groups are different from each other on a particular in interval-scaled or ratio-scaled variable of interest. Hence, this experiment is established to test a nominal variable that is split into two subgroup like other past literature studies such as Syariah and Non-Syariah firms, family and non-family companies, younger and older employees and so on (Sekaran \& Bougie, 2009). For this study, domestic banks and foreign banks will be focused and separated into the two subgroups and will be tested to see if there is any significant in mean difference between 
this two independent groups on the dependent variables. The differences between the bank's corporate governance (board size and independent director), financial performance (liquidity, profitability, risk and solvency and efficiency) and banks characteristics (firm size) of these two types of banks will be measured on a ratio scale and interval scale.

\begin{tabular}{|c|c|c|c|}
\hline \multirow[t]{2}{*}{ Variables } & $\begin{array}{c}\text { Domestic } \\
\text { Banks } \\
(\mathrm{N}=8)\end{array}$ & Foreign Banks $(\mathrm{N}=16)$ & \multirow[t]{2}{*}{ t-statistics } \\
\hline & Mean & Mean & \\
\hline \multicolumn{4}{|l|}{ A: Corporate Governance } \\
\hline Board Size & 9.6750 & 6.4250 & 5.901 \\
\hline Independent Director Proportion & 0.533546 & 0.472324 & 1.481 \\
\hline \multicolumn{4}{|l|}{ B: Financial Performance of banks } \\
\hline Current ratio (CR) & 1.029360 & 1.634356 & $-2.666^{* *}$ \\
\hline Return on Asset (ROA) & 0.010897 & 0.006282 & $3.103^{*}$ \\
\hline Loan to Deposit ratio (LDR) & 0.815687 & 0.660496 & $1.388^{* *}$ \\
\hline Asset Utilization (AU) & 0.024494 & 0.025433 & -0.266 \\
\hline \multicolumn{4}{|l|}{ C: Banks Characteristics } \\
\hline Firm Size & 18.983067 & 15.945115 & $5.660 * *$ \\
\hline
\end{tabular}

** significant at 0.10 level

* significant at 0.05 level

Further examination of the comparisons disclose that domestic banks experience higher profitability with the average return on asset (ROA) at $1.0897 \%$, which is significantly higher than foreign banks at $0.6282 \%$. Hence, the difference is statistically different with p-value less than 0.05 level as shown in Table 5. This result is consistent with the empirical study by Al-Mamun, Rafique Yasser, Entebang, Rahman, Nathan, Abu Mansor (2015). Hence, this result support the hypothesis of $\mathrm{H} 4 \mathrm{~b}$, which stated that there is a significant, difference in return on asset (ROA) mean between domestic banks and foreign banks. Furthermore, the board size of foreign banks (mean=9.6750) is much smaller than domestic banks (mean=6.4250). The result reveals that there is a statistically insignificant difference between the board size of domestic banks and foreign banks. Apart from that, the comparisons also show that current ratio (CR) of domestic banks is significantly lower than foreign banks. On the other hand, the efficiency of both banks does not show any significant difference in value. This result supports the literature of Ika and Abdullah (2011) who mentioned that there is no major difference in financial performance between domestic banks and foreign banks. Besides, firm size (FS) of domestic banks also indicates significantly higher and larger value compared to foreign banks. This is because the domestic banks have more total assets, which indirectly expands their firm size (asset hold) compared to foreign banks, as per illustration in Table 1 and 2 of total assets of the overall domestic banks in Malaysia versus total assets of overall foreign banks in Malaysia respectively .

\subsection{Comparison between Domestic Banks and Foreign Banks for year 2012- 2016}

\subsubsection{Current Ratio(CR)}

The trend of current ratio for foreign banks show an obvious decline in 2014 between the year of 2012 to 2016 as shown in Figure 3, whereas, current ratio for domestic banks is quite stable and stagnant from the year of 2012 to 2016. However, in general foreign banks have a more and better liquidity performance compared to domestic banks in all five years from 2012 to 2016.This may be due to domestic banks contain a larger board which result in a higher liquidity risk compared to locally incorporate foreign banks. 
Figure 3: Comparison between domestic banks and foreign banks by using an annual average of current ratio for year 2012-2016

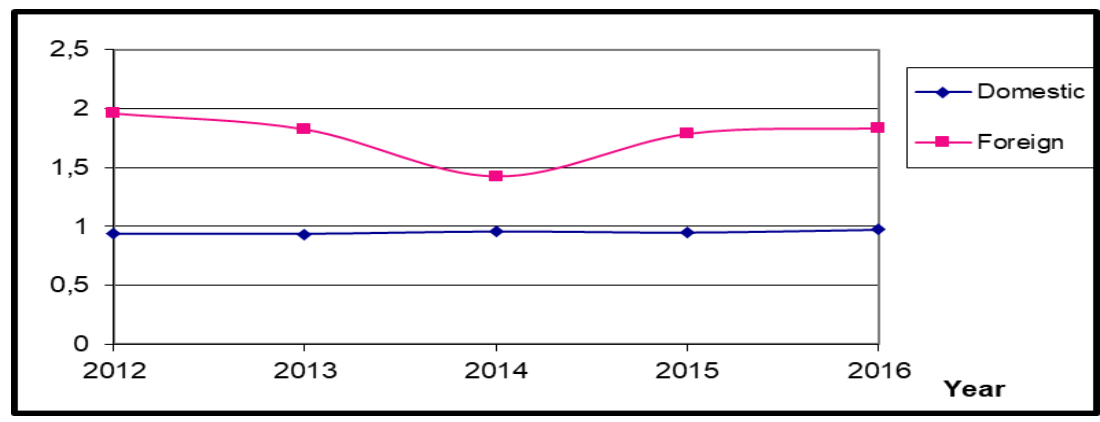

\subsubsection{Return of Assets (ROA)}

Based on Figure 4, both types of banks were having unstable fluctuations where there were ups and downs in their profitability in terms of Return on Assets (ROA) throughout the period from year 2012 to 2016. However, the return on assets ratio of domestic banks has outperformed the foreign banks in during the 5 years period. This may due to the fact that a well-capitalized bank will generate higher profitability due to lower cost of borrowing but on the contrary is possible otherwise. The results show also, although the negative relationship between economic growth and profitability in the Malaysian banks, high inflation rate affect them positively (Sufian, 2009).

Figure 4: Comparison between domestic banks and foreign banks by using an annual average of return on assets for year 2012-2016

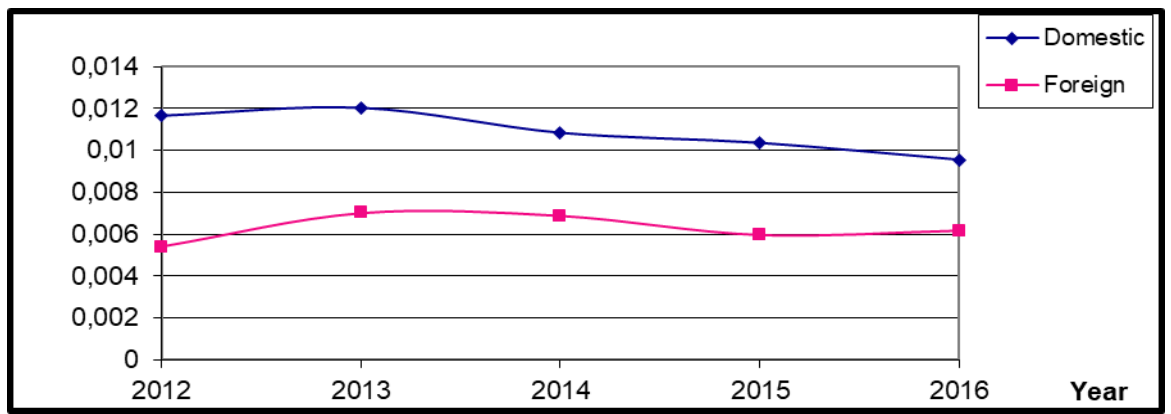

\subsubsection{Loan to Deposit Ratio (LDR)}

Figure 5 displays the loan to deposit ratio of domestic banks and foreign banks are both stable which experienced a slightly incline from year 2012 to 2016 . However, both of the banks may not earn much and may rely on its own deposits to make loan to its customers, without any borrowing since the loan to deposit ratio is less than 1. A good loan to deposit ratio for a bank is between 80 and 90 percent as of 2014, according to Forbes. An 80 percent ratio means for every $\$ 1$ a bank receives in deposits it loans 80 cents to businesses or consumers, in which we identify that domestic banks have a better risk and solvency management compared to foreign banks. In the context of Malaysia, which is more relevant and related to this study, analysis on the factors influencing bank profitability in Malaysia covering the period 2000-2004 by past study researcher, Sufian (2009) and he focuses specifically on foreign and domestic commercial banks. He comes up with the results that there is a negative relationship between credit risk and loan concentrated for Malaysian banks. Therefore, the higher the credit risks of a bank, then the more its exposure to loan payment, which will result consequently in a low level of profitability. In fact, this statement can explain why the return to its assets through ROA kept dropping for domestic banks starting from the year of 2013 as there are more credit risks that the domestic banks exposed to its loan. 
Figure 5: Comparison between domestic banks and foreign banks by using an annual average of loan to deposit ratio for year 2012-2016

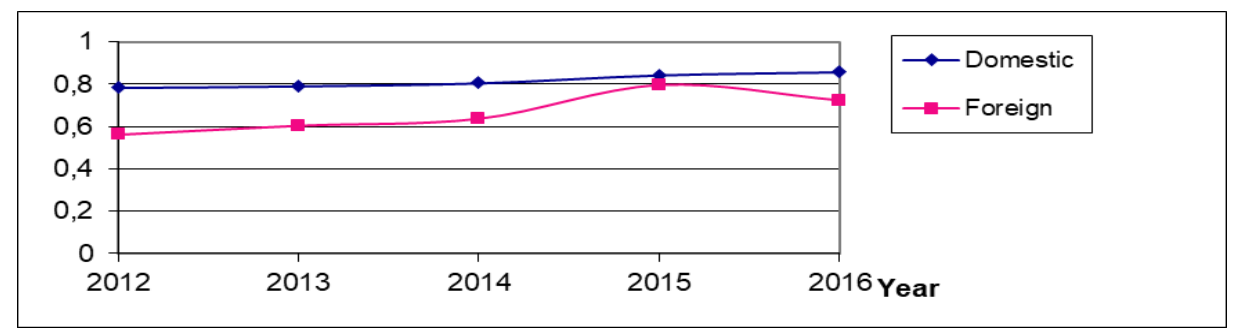

\subsubsection{Asset utilization Ratio (AU)}

Figure 6 shows that the trend of the asset utilization ratio for both type of banks are moved in from year 2012 to 2016 in which both trends are going on a downward trend throughout the period. The foreign banks had outperformed the domestic banks throughout the whole period except in the year of 2015, Hence, in overall the foreign banks perform better in term of bank's efficiency in utilizing its company's assets to generate returns in order to compete for efficiency through scale and scope economies.

Figure 6: Comparison between domestic banks and foreign banks by using an annual average of asset utilization ratio for year 2012-2016

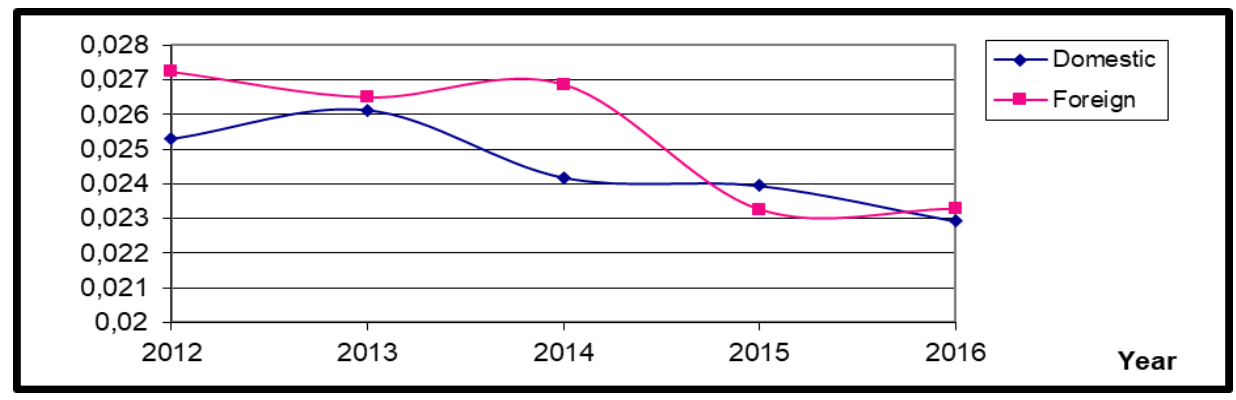

\subsubsection{Correlation Analysis}

Pearson Product-Moment Correlations was used to determine the inter-correlation between all our study variables which are board size (BS), independent director proportion (IDP), firm size (FS),current ratio (CR), return on assets (ROA), loan to deposit ratio (LDR) and asset utilization ratio (AU). Table 6 below shows the summary of the results.

\begin{tabular}{|c|c|c|c|c|c|c|c|}
\hline & BS & IDPP & CR & ROA & LDR & $\mathbf{A U}$ & FS \\
\hline Board size (BS) & 1 & & & & & & \\
\hline $\begin{array}{l}\text { Independent director } \\
\text { proportion (IDP) }\end{array}$ & $0.447 *$ & 1 & & & & & \\
\hline Current ratio (CR) & -0.301 & $-0.450 *$ & 1 & & & & \\
\hline Return on Asset (ROA) & $0.624^{* *}$ & $0.531^{* *}$ & -0.290 & 1 & & & \\
\hline $\begin{array}{l}\text { Loan to deposit ratio } \\
\text { (LDR) }\end{array}$ & $0.451^{*}$ & 0.206 & $0.425^{*}$ & $0.534^{* *}$ & 1 & & \\
\hline $\begin{array}{l}\text { Asset utilization ratio } \\
\text { (AU) }\end{array}$ & 0.164 & 0.270 & -0.085 & 0.356 & 0.037 & 1 & \\
\hline Firm size (FS) & $0.792 * *$ & $0.623^{* *}$ & $-0.559 * *$ & $0.795^{* *}$ & 0.355 & 0.170 & 1 \\
\hline
\end{tabular}

*. Correlation is significant at the 0.05 level (2-tailed).

**. Correlation is significant at the level 0.01 level (2-tailed).

From the result, the current ratio of banks are insignificantly negative correlated $(-0.301)$ to the board size and significantly negative correlated $(-0.450)$ to the proportion of independent directors in banks, which means that the bigger the board size in the organization will lead to a poorer or lower level of liquidity in the company as one of the reasons might due to the high outflow of cash to the directors as dividends and bonuses. In terms of profitability, the return on 
assets of banks is significantly positive correlated (0.624) to the board size as well as significantly positive correlated (0.531) to the proportion of independent directors in banks, which means that the bigger the board size and the more independent directors on board, it will lead to a higher chance to generate a good return on the invested assets in the company itself. On the other hand, in terms of risk and solvency, the loan to deposit ratio of banks are significantly positive correlated $(0.451)$ to the board size and insignificantly positive correlated $(0.206)$ to the proportion of independent directors in banks, which means that the bigger the board size and the more independent directors on board, it will lead to good generation on the issue of loans out of the deposits that the banks have collected from its customers as well as the financial institutions. In addition, in terms of efficiency, the asset utilization ratio of banks is insignificantly positive correlated $(0.164)$ to the board size and insignificantly positive correlated $(0.270)$ to the proportion of independent directors in banks. Nonetheless, when the bank's board size and portion of independent directors in board increases, the risk and solvency performance of banks and efficiency of banks will increases.

Furthermore, the firm size of banks is significantly positive correlated (0.792) to the board size and significantly positive correlated $(0.623)$ to the proportion of independent directors in banks, which means that when the bank has a larger firm size in terms of total assets, it will involve a bigger the board size and more independent directors on board, however it is significantly negative correlated to its current ratio and significantly positive correlated to its return on assets of the banks. But, the control variable of firm size is insignificantly positive correlated to its loan to deposit ratio and asset utilization ratio.

\subsection{Multiple Regression Results}

The data in this study is analyzed by using the multiple regression (panel data analysis) method. Table 5 summarizes the regression results of the model for domestic banks and foreign banks for the period of 2012 to2016.

\begin{tabular}{lccc} 
Table 7: The Regression Models for Current Ratio (CR) & \multicolumn{1}{c}{} \\
\hline Variables & Full Sample & Domestic Banks & Foreign Banks \\
\hline Intercept & 6.502 & 6.187 & 6.680 \\
Board Size & $(3.093)^{* * *}$ & $(0.811)$ & $(5.767)^{* * *}$ \\
Independent Director Proportion & 0.308 & 0.460 & 0.144 \\
Firm Size (ln asset) & $(3.092)^{* * *}$ & $(2.118)^{* *}$ & $(1.304)$ \\
& -2.432 & -5.325 & -0.535 \\
& $(-1.642)$ & $(-1.515)$ & $(-0.402)$ \\
& -0.351 & -0.333 & -0.352 \\
Observation & $(-3.071)^{* * *}$ & $(-0.789)$ & $(-3.411)^{* * *}$ \\
R2 & & & 80 \\
Adj. R2 & 120 & 40 & 0.222 \\
F-stat (p-value) & 0.160 & 0.173 & 0.192 \\
\end{tabular}

${ }^{* * *}$ significant at 0.01 level. ${ }^{* *}$ significant at 0.05 level. * significant at 0.10 level

As for domestic banks shown in Table 5, board size (BS) shows a significant and positive relationship with current ratio (CR) for the overall period at significance level of5\%. This result does not coherent with the previous study carried by Delis, Gganis and Pasiouras (2009), however it is consistent with the finding from Adams and Mehran (2012) supports the hypothesis H1a that stated the board size relates negatively to liquidity ratio. The reason behind is that larger boards are better due to the board structure that consists of members from diverse background that brings different skills and professional expertise to the board. As a result, it would promote better decision-making and offer the board a better opportunity and position to monitor the operation of management. Therefore, the larger the board, the better the performance of the company. This position is premised on the assumption that larger boards are constituted with members from different backgrounds that brings to the board different skills and professional expertise. This would facilitate better decision making and place the board in a better position to monitor the activities of management, where all these were supported by Tornyeva and Wereko (2012)'s research study. Based on Table 6, it displays the same result that one of the independent variable, bank's independent directors proportion has no significant positive or negative relationship with the current ratio (CR) of both types of banks. Meanwhile, firm size (FS) has significant and negative relationship with the current ratio (CR) for full sample and foreign banks at $1 \%$ significant level. 


\begin{tabular}{lccc}
\multicolumn{4}{l}{ Table 8: The Regression Models for Return on Asset (ROA) } \\
\hline Variables & Full Sample & Domestic Banks & Foreign Banks \\
\hline Intercept & -0.023 & 0.165 & -0.036 \\
Board Size & $(-6.320)^{* * *}$ & $(3.860)^{* * *}$ & $(-7.106)^{* * *}$ \\
Independent Director Proportion & 0.000 & -0.001 & 0.001 \\
Firm Size (ln asset) & $(0.664)$ & $(-1.869)^{*}$ & $(2.131)^{* *}$ \\
& -0.001 & 0.004 & -0.009 \\
& $(-0.126)$ & $(0.935)$ & $(-1.495)$ \\
& $0.002^{* * *}$ & $-0.008^{* * *}$ & $0.002^{* * *}(5.564)^{* * *}$ \\
\hline Observation & $(5.381)^{* * *}$ & $(-3.614)^{* * *}$ & \\
R2 & & & 80 \\
Adj. R2 & 120 & 40 & 0.503 \\
F-stat (p-value) & 0.445 & 0.721 & 0.484 \\
& 0.431 & 0.624 & $25.682(0.000)$ \\
\hline
\end{tabular}

*** significant at 0.01 level. ** significant at 0.05 level. * significant at 0.10 level

Based on findings shown in Table 8, board size has a significant relationship with the profitability for both banks, but domestic has negatively related meanwhile foreign banks have positively related to ROA. Therefore, for foreign bank, the result is consistent with Switzer and Sahut (2015) and Belkhir (2009) indicating that the larger and diversified the board could benefit banks in distress states or when credit risk was overriding. However, independent directors for both domestic banks and foreign banks do not showed any significant relationship with the return on asset (ROA). This means that the appearance of independent director of banks do not give any impact on the profitability of banks. Yet, the foreign banks' firm size (FS) has a significant and positive relationship with return on asset at $1 \%$ significant level. This may due to the establishment and presence of foreign banks in other countries provides advantages for foreign banks to achieve high profitability. In overall of full sample, it also shows that the firm age as well as the firm size (FS) (which measured based on the total assets hold by banks) will positively and significantly influence the profitability of banks.

\begin{tabular}{lccc} 
Table 9: The Regression Models for Loan to Deposit Ratio (LDR) & \\
\hline Variables & Full Sample & Domestic Banks & Foreign Banks \\
\hline Intercept & -0.125 & -2.937 & -0.586 \\
Board Size & $(-0.402)$ & $(-3.577)^{* * *}$ & $(-1.194)$ \\
Independent Director Proportion & 0.041 & -0.011 & 0.126 \\
Firm Size (ln asset) & $(1.683)^{*}$ & $(-2.024)^{*}$ & $(2.689)^{* * *}$ \\
& 0.036 & -0.030 & -0.049 \\
& $(0.099)$ & $(-0.392)$ & $(-0.087)$ \\
& 0.030 & 0.204 & $0.029(0.670)$ \\
Observation & $1.089)$ & $(4.833)^{* * *}$ & \\
R2 & & & 80 \\
Adj. R2 & 120 & 40 & 0.162 \\
F-stat (p-value) & 0.125 & 0.878 & 0.129 \\
\hline
\end{tabular}

*** significant at 0.01 level. ** significant at 0.05 level. * significant at 0.10 level

According to findings as shown in Table 9, it shows only one of the independent variable, bank's board size has a significant positive relationship with loan to deposit ratio (LDR) for full sample and foreign banks, but negatively related for domestic banks. For domestic banks, the results of smaller board size lead to higher LDR consistent with Switzer and Sahut (2015), who find that when banks were in financial distress, their investment policies will be tightened up, and default was very likely, hence, smaller boards are getting higher chances to bankrupt. Meanwhile, independent director proportion shows an insignificant and positive relationship with loan to deposit ratio (LDR), since the result is proven to be not significant, hence this carries the meaning of the corporate governance, such as independent director within the organization of bank does not have any significant impact on the risk and solvency of domestic banks and foreign banks. 
Table 10: The Regression Models for Asset Utilization ratio (AU)

\begin{tabular}{lccc} 
Variables & Full Sample & Domestic Banks & Foreign Banks \\
\hline Intercept & 0.173 & 0.196 & 0.044 \\
Board Size & $(6.602)^{* * *}$ & $(3.346)^{* * *}$ & $(2.784)^{* * *}$ \\
Independent Director Proportion & 0.001 & -0.001 & 0.002 \\
& $(1.240)$ & $(-1.350)$ & $(3.043)^{* * *}$ \\
& -0.009 & -0.002 & 0.005 \\
Firm Size (lnasset) & $(-1.141)$ & $(-0.435)$ & $(0.424)$ \\
& -0.009 & -0.009 & -0.002 \\
Observation & $(-5.852)^{* * *}$ & $(-2.884)^{* * *}$ & $(-2.089)^{* *}$ \\
R2 & 120 & 40 & 80 \\
Adj. R2 & 0.795 & 0.958 & 0.110 \\
F-stat (p-value) & 0.737 & 0.944 & 0.075 \\
\hline
\end{tabular}

*** significant at 0.01 level. ** significant at 0.05 level. * significant at 0.10 level

Table 10 displays the result shows one of the independent variable, bank's independent directors proportion has no significant and positive or negative relationship with the asset utilization ratio (AU) of both types of banks. However, board size has positively significant influence on asset utilization ratio for foreign banks at $1 \%$ significant level indicating that the bank's corporate governance will directly affect on the efficiency of bank.

\section{Conclusion}

The board size of banks showed a positive relationship on the liquidity performance of domestic banks. The findings of board size consistent with the past literatures (Delis, Gganis \& Pasiouras, 2009) have shown significant influences in the liquidity performance of banks. In this study, board size has shown a positive impact and influence on the current ratio of banks. Foreign bank shows insignificant relationship with level of liquidity despite only domestic bank's result shows a significant positive relationship between board size and the bank's level of liquidity. Therefore, it can be deemed that the larger the board sizes of a domestic bank, the greater the level of liquidity it will be. However, the size of a board that a firm or a bank could afford certainly depends on the current firm size and the level that could the bank host.

In addition, either in domestic banks or foreign banks, independent director has no significant relationship with all the financial performance of domestic banks and foreign banks. Independent director or board independency does not create significant positive or negative impact towards the liquidity (CR), profitability (ROA), risk and solvency (LDR) and efficiency (AU) of both banks. Therefore, as such, findings of this study are not consistent with research of Delis, Gganis and Pasiouras (2009), which stated that banks with more independent directors showed significant higher liquidity; study from Ghaffar (2014), who explained that bank profitability was significantly and positively influenced by board independency; the literature by Switzerand Sahut (2015) and findings from Dionne and Triki (2005) which disclosed that percentages of independent directors will related negatively and positively to risk and solvency ratio as well as efficiency ratio respectively.

Interestingly, the mean difference between domestic banks and foreign banks reveal a strong significant difference between the profitability, liquidity and risk and solvency. This may due to the difference between policies and ways of operation applied by two banks. This study indicated that domestic banks tend to perform better in profitability. However, the other findings of this study is not supported by the past literatures such as researches from Rosly and Abu Bakar (2003), Ika and Abdullah (2011), Ansari and Rehman (2010) and Shaikh, Sharif and Arif (2014). Some of these researches identified the domestic banks have a higher liquidity, lower risk and solvency and lower efficiency while foreign banks showed an opposite results. However, in this study, the findings of LDR of domestic banks are slightly higher than foreign banks. Meanwhile, the results do not show statistically significant difference in mean for asset utilization (AU) between domestic banks and foreign banks.

\section{Appendix A. Supplementary material}

Supplementary data associated with this article can be found, in the online version, at https://doi.org/10.14254/jems.2018.3-2.4 


\section{Funding}

The authors received no direct funding for this research.

\section{Citation information}

Ibrahim, H., Xiang, Ng. Yi., Nik Azman, N. H. N., \& Zulkafli, A. H. (2018). Comparative study on board structure and performance between domestic and foreign banks in Malaysia. Economics, Management and Sustainability, 3(2), 42-59. doi:10.14254/jems.2018.3-2.4.

\section{References}

Al-Mamun, A., Yasser, Q. R., \& Entebang, H. (2014). Comparison between Islamic and Conventional Banking : Evidence from Malaysia. International Journal of Excellence in Islamic Banking and Finance, 4(1), 1-14. https://doi.org/10.12816/0006958

Andres, P. De, \& Vallelado, E. (2008). Corporate governance in banking: The role of the board of directors. Journal of Banking \& Finance, 32(12), 2570-2580. https://doi.org/10.1016/j.jbankfin.2008.05.008

Ansari, S. (2009). Financial Performance of Islamic and Conventional Banks in Pakistan: A Comparative Study, 1-19.

Azhar Rosly, S., \& Afandi Abu Bakar, M. (2003). Performance of Islamic and mainstream banks in Malaysia. International Journal of Social Economics, 30(12), 1249-1265. https://doi.org/10.1108/03068290310500652

Azhar Rosly, S., \& Afandi Abu Bakar, M. (2003). Performance of Islamic and mainstream banks in Malaysia. International Journal of Social Economics, 30(12), 1249-1265. https://doi.org/10.1108/03068290310500652

BarNir, A., Gallaugher, J. M., \& Auger, P. (2003). Business process digitization, strategy, and the impact of firm age and size: the case of the magazine publishing industry. Journal of Business Venturing, 18(6), 789-814. https://doi.org/10.1016/S0883-9026(03)00030-2

Belkhir, M. (2009). Board of directors' size and performance in the banking industry. International Journal of Managerial Finance, 201-221. https://doi.org/10.1108/17439130910947903

Claessens, S., Demirgüç-Kunt, A., \& Huizinga, H. (2001). How does foreign entry affect domestic banking markets?. Journal of Banking \& Finance, 25(5), 891-911.

Cornett, Adair \& Nofsinger (2015). Corporate Finance, $3^{\text {rd }}$ Edition.

Dionne, G., \& Triki, T. (2005). Risk management and corporate governance: The importance of independence and financial knowledge for the board and the audit committee. Cahier de recherche/Working Paper, 5, 15.

Donaldson, L., \& Davis, J. H. (1991). Stewardship theory or agency theory: CEO governance and shareholder returns. Australian Journal of Management, 16(1), 49-64.

Eisenhardt, K. M. (1989). Agency theory: An assessment and review. Academy of management review, 14(1), 57-74.

Fries, S., \& Taci, A. (2005). Cost efficiency of banks in transition: Evidence from 289 banks in 15 post-communist countries. Journal of Banking \& Finance, 29(1), 55-81.

Gul, S., Irshad, F., \& Zaman, K. (2011). Factors Affecting Bank Profitability in Pakistan. Romanian Economic Journal, 14(39).

Jensen, M. C. (1986). Agency costs of free cash flow, corporate finance, and takeovers. The American Economic Review, 76(2), 323-329.

Jensen, M. C. (1993). The modern industrial revolution, exit, and the failure of internal control systems. the Journal of Finance, 48(3), 831-880.

Kosmidou, K., Pasiouras, F., Doumpos, M., \& Zopounidis, C. (2004). Foreign versus domestic banks' performance in the UK: a multicriteria approach. Computational Management Science, 1(3-4), $329-343$. 
Kosmidou, K., Pasiouras, F., Zopounidis, C., \& Doumpos, M. (2006). A multivariate analysis of the financial characteristics of foreign and domestic banks in the UK. Omega, 34(2), 189-195.

Levine, R. (1996). IForeign Banks, Financial Development and Economic Growth, International Fi\& financial Markets: Harmonization versus Competition.

Matthews, K., \& Ismail, M. (2006). Efficiency and productivity growth of domestic and foreign commercial banks in Malaysia (No. E2006/2). Cardiff economics working papers.

Pathan, S. (2009). Strong boards, CEO power and bank risk-taking. Journal of Banking \& Finance, 33(7), 1340-1350. https://doi.org/10.1016/j.jbankfin.2009.02.001

Pathan, S., Skully, M., \& Wickramanayake, J. (2008). Board Size, Independence and Performance: An Analysis of Thai Banks. Asia-Pacific Financial Markets, 14(3), 211-227. https://doi.org/10.1007/s10690-007-9060-y

Rowe, W., Shi, W., \& Wang, C. (2011). Board governance and performance of Chinese banks. Banks and Bank Systems, 1.

Sekaran, U., \& Bougie, R. (2009). Research Methods for Business: A Skill-Building Approach. 5th Edition, John Wiley and Sons Inc., Hoboken.

Staikouras, Ch., \& Wood, G. (2003). The determinants of bank profitability in Europe. In: Paper presented at the Proceedings of the European Applied Business Research Conference, Venice, Italy, June 9-13, 2003.

Stiglitz, J. E. (1993). The role of the state in financial markets. The World Bank Economic Review, 7(suppl_1), 19-52.

Sufian, F. (2009). Determinants of bank efficiency during unstable macroeconomic environment: Empirical evidence from Malaysia. Research in International Business and Finance, 23(1), 5477.

Sufian, F. (2009). Factors influencing bank profitability in a developing economy: Empirical evidence from Malaysia. Global Business Review, 10(2), 225-241.

Sufian, F. (2010). Developments in the performance of the Malaysian banking sector: opportunity cost of regulatory compliance. International Journal of Business Competition and Growth, 1(1), 85-103.

Walter, I., \& Gray, H. P. (1983). Protectionism and international banking: Sectorial efficiency, competitive structure and National policy. Journal of Banking \& Finance, 7(4), 597-609.

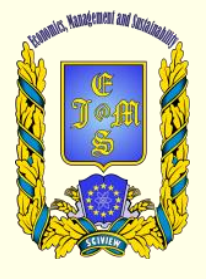

๑) 2016-2018, Economics, Management and Sustainability. All rights reserved. This open access article is distributed under a Creative Commons Attribution (CC-BY) 4.0 license.

You are free to:

Share - copy and redistribute the material in any medium or format Adapt - remix, transform, and build upon the material for any purpose, even commercially.

The licensor cannot revoke these freedoms as long as you follow the license terms.

Under the following terms:

Attribution - You must give appropriate credit, provide a link to the license, and indicate if changes were made.

You may do so in any reasonable manner, but not in any way that suggests the licensor endorses you or your use.

No additional restrictions

You may not apply legal terms or technological measures that legally restrict others from doing anything the license permits.

Economics, Management and Sustainability (ISSN: 2520-6303) is published by Scientific Publishing House "CSR",

Poland, EU and Scientific Publishing House "SciView", Poland

Publishing with JEMS ensures:

- Immediate, universal access to your article on publication

- High visibility and discoverability via the JEMS website

- Rapid publication

- Guaranteed legacy preservation of your article

- Discounts and waivers for authors in developing regions

Submit your manuscript to a JEMS at http://jems.sciview.net or submit.jems@sciview.net

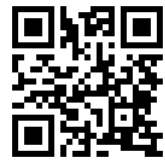

